\title{
RISK MANAGEMENT THEORY: THE INTEGRATED PERSPECTIVE AND ITS APPLICATION IN THE PUBLIC SECTOR
}

\author{
Ignacio Cienfuegos Spikin \\ i.j.cienfuegosspikin@utwente.nl. \\ Universiteit Twente.Holanda.
}

This article aims to discuss in a normative way, the foundations of the theory of risk management, showing its evolution and reviewing the main best practices. As consequence, after a quick description of the current environment into which public and private organizations currently struggle, we proceed to develop a clear definition of risk. We introduce then, the fundamental aspects of risk management and the practices prescribe in the literature. Moreover, we describe the fundamental elements that have marked the transition from the "silo" approach or compartmental perspective of risk management, to the integrated risk management approach. At the end of the article, we discuss the application of risk management in the public sector, describing its difference from private risk management.

Keywords: Risk; Risk Management; Integrated Risk Management; Risk Management process and Public Risk Management.

\section{TEORÍA DE LA GESTIÓN DE RIESGOS: UNA PERSPECTIVA INTEGRADA Y SU APLICACIÓN EN EL SECTOR PÚBLICO}

El presente artículo tiene por objeto presentar de manera normativa, los fundamentos de la teoría de gestión de riesgos, describiendo su evolución y mejores prácticas. Luego de una breve discusión sobre el contexto en el que organizaciones tanto públicas como privadas operan, se ofrece una definición de riesgo y sus principales características. A continuación, introducimos los principales aspectos de la disciplina de gestión de riesgos y practicas prescritas en la literatura. Posteriormente analizamos los elementos que marcan la transición desde la perspectiva de "silo" hacia el enfoque integrado de gestión de riesgos. Al final del documento, nos referimos a la aplicación de la gestión de riegos en el sector público, describiendo sus diferencias con la gestión de riesgos privada.

Palabras clave: Riesgo, Gestión de Riesgos, Gestión de Riesgos integrada, Proceso de Gestión de Riesgos y Gestión de Riesgos Pública. 


\section{ENVIRONMENTAL COMPLEXITY}

The word 'risk' has become a common and widely used part of today's vocabulary, considering personal circumstances (health, pensions, insurance, investments, etc.), society (terrorism, economic performance, food safety, etc.) and also business (corporate governance, strategy, business continuity, etc.). Many of the institutions that humanity has built as well, could be viewed as a way to address uncertainty, including politics, religion, philosophy, technology, laws, ethics and morality (Hillson, 2006). Therefore its seems that the human wisdom has been capable of identifying patterns for uncertainty and develop heuristics to comfort it. As a result, not only is risk everywhere, but so is risk management. As stated by Hillson, (2006), just as the presence of risk is recognized and accepted as inevitable and unavoidable in every field of human endeavor, so there is a matching drive to address risk as far as possible.

As mentioned by Pavodani and Tugnoli (2005) there are clear elements that could explain the current importance of the discipline of risk management. First of all, the increasing volatility and competition which organizations have to face in this era, have forced them to implement at least some level of risk awareness. On the other hand and related to some very notorious international scandals such as the Enron case, WorldCom and more recently Lehman Brothers, organizations in general are facing legal requirements by the authorities and regulators, who are demanding the implementation of increasingly more sophisticated risk management practices. Moreover, as technology has helped organizations to be more efficient, it has also exposed them to different sorts of new significant threats. As claim by Pavodani and Tugnoli (2005) the elements described have created new risks and increase the impact and frequency of existing risks. Hence the modern recognition of risk management as a process that complements and integrates with other processes in the organization, in a continuous and formalized manner, might be a pertinent approach to the reality that entities face. In this sense, the process of risk management becomes not only an instrument to prevent and manage the impact of damaging events on the organization, but a force to see opportunities (Pavodani and Tugnoli, 2005). 


\section{The Concept of Risk}

Risk has been defined in a number of ways, which are almost never entirely true or false, but are useful tools for abstraction and creating common focal points (Rosa 1998 in Habegger, 2008). A dictionary definition considers that risk is 'the chance of injury, damage or loss' (Webster, 1983 in Habegger, 2008). Following that perspective risk would not be predestined, but subject to human agency (Habegger, 2008). Additionally we might distinguish between the meaning of the concept in technical and non-technical contexts. Therefore in technical contexts, the concept of 'risk' could have specific meanings which are widely used across disciplines, ranging from 'the cause of, the probability of, or an unwanted event which may or may not occur' to a decision that has been made under the condition of known probabilities. Rosa (2003 in Habegger, 2008) added to this conception the element of uncertainty, by defining risk as a situation or an event where something of human value (including humans themselves) is at stake and where the outcome is uncertain.

In the same manner, Terje and Ortwin (2009) consider that although there wouldn't be an agreed general definition of risk in the literature, there might be some common characteristics that we can mention:

1. Risk equals the expected loss (Willis, 2007)

2. Risk equals the expected disutility (Campbell, 2005)

3. Risk is the probability of an adverse outcome (Graham and Weiner, 1995)

4. Risk is a measure of the probability and severity of adverse effects (Lowrance 1976).

5. Risk is the fact that a decision is made under conditions of known probabilities (Knight, 1921).

6. Risk is the combination of probability of an event and its consequences (ISO, 2002).

7. Risk is defined as a set of scenarios, each of which has a probability and a consequence (Kaplan and Garrick 1981; Kaplan 1991) 
8. Risk is equal to the two-dimensional combination of events/ consequences and associated uncertainties (will the events occur, what will be the consequences) (Aven 2007).

9. Risk refers to uncertainty of outcome, of actions and events (Cabinet Office 2002)

10. Risk is an uncertain consequence of an event or an activity with respect to something that human's value (IRGC, 2005).

\subsection{THE CONCEPT OF UNCERTAINTY}

As stated by Knight (1921 in Hermans et al., 2012) it might be possible to distinguish risk form uncertainty. According to this influential author then, risk can be explained as "you don't know for sure what will happen", while uncertainty would refer to "you don't even know the odds of what will happen" (Adams, 2005 in Hermans et al., 2012). Therefore in that sense uncertainty would be immensurable and not calculable whereas risk would be measurable by using the formula: risk $=$ chance $\mathrm{x}$ effect (Hermans et al., 2012).

Uncertainty can be viewed then as the variability surrounding a risk, or to put it in another way, the range of outcomes that may results from the occurrence of a risky event. As mentioned by Binmore, (2009) the archetypal case of uncertainty is betting at the race track, when there is no sense to attribute a probability to such a one-off occurrence. By revising the literature on risk management we could observe also different approaches of uncertainty. For example Frank (1999), in Van Staveren, 2009), discriminates "aleatory uncertainty" from "epistemic uncertainty". Aleatory uncertainty would refer to the variation and change, while epistemic uncertainty addressees the lack of knowledge. The individual conviction or lack of knowledge (certain or uncertainty) about a specific situation may or not coincide with the conditions of the real world. As mentioned by (Vaughan, 1997) different attitudes would be possible for different individuals under identical conditions, therefore uncertainty would be also related with the perception of risk by individuals (Slovic, Monahan and MacGregor, 2000).

Under this perspective risk appears to mean different things to different people, and actions and understandings about risks would be learned by socially and 
culturally structured conceptions and evaluations of the world (Boholm, 1998). As a consequence, these differences could be based on different information, interests, or perceptions about reality and how we come to perceive it. In the literature for instance, we might find multiple conceptions of risk (Slovic 1987; Rayner 1988) and some of them might be even competing (Douglas and Wildavsky 1982; Shrader- Frechette 1991). Disputes about competing conceptions of risk take the form of principled and reasoned disputes, as opposed to simple misunderstandings (Thompson and Dean 1996). Moreover competing conceptions would not only differ in their definitions of risk, but also reflect philosophical differences that are longstanding and systematically linked (Rosa 1998).

\subsection{DifFERENT APPLICATIONS OF RISK}

Despite these possible theoretical disputes in the conception of risk mentioned before, we should focus in our case, in the different application of the concept in social science. In finance for instance, risky options involve monetary outcomes with explicit probabilities and they are evaluated in terms of their expected value and their riskiness (Olson and Desheng, 2008). Thus the traditional approach to risk in finance literature is based on a mean-variance framework of portfolio theory (Markowitz, 1952). Moreover the idea of risk in finance would be understood within the scope of systematic (non-diversifiable) risk and unsystematic (diversifiable) risk (Gehr, 1979). Another established concern in finance is default risk and it is often argued that the performance of the firm is linked to the firm's default risk (Shapiro and Titman, 1986). A large part of the literature on risk on finance, deals as well with several techniques to measure the risk of the firm's investment portfolio (e.g., standard deviation, beta, Var, etc.) (Babcock, 1972 in Olson and Desheng, 2008).

Risk in economics on the other hand, is understood within two separate categories, endogenous (controllable) risk and background (uncontrollable) risk (Olson and Desheng, 2008). Thus, it is recognized by scholars that economic decisions are made under uncertainty in the presence of multiple risk (Eckhoudt, Gollier and Schlesinger, 1996). Therefore we can say that economics, or to be more precise Neoclassic economy, argue that people would be risk averse when the size of 
the risks would be large (Friedman and Savage, 1948). Therefore in economics, the concept of risk-bearing preferences of agents for independent risk would be described under the notion of "standard risk aversion".

While the economist assumes an individual's risk preferences as a function of probabilistic believes, psychology would explore how human judgment and behavior systematically forms such beliefs (Rabin, 2000 in Olson and Desheng, 2008). As a consequence, psychology mainly concentrates in the risk taking behavior (risk preferences) (Olson and Desheng, 2008). Therefore this discipline searches for the patterns of human reactions to the context, reference point, mental categories and associations that influence how people make decisions. According to Willett (1951 in Olson and Desheng, 2008), risks might affect economic activity through the psychological influence of uncertainty. Risk perception plays a central role in psychology, where the key concern is how individual perceives risk and how it differs from the actual outcome (Slovic, 1987, Slovic and Fischoff and Lichtenstein, 1979).

Additionally the sociological perspective on risk was originated from the psychological and anthropological view of the discipline. Consequently, we could mention that for sociology risk would be dominated by two central issues; the relationship between risk and culture (Douglas and Wildavsky, 1982) and the development involving risk and society (Beck, 1992). In that sense the negative consequences of unwanted events would be the principal concerns of sociological research on risk. Thus on sociology, the term risk would be socially constructed and therefore considered a social problem. From a sociological perspective then, entrepreneurs remain liable for the risk the society and responsible to share it in proportion to their respective contributions (Olson and Desheng, 2008).

Furthermore and in philosophic terms, research on risk would discuss the way in which this discipline may be used to clarify important value issues and ethic situation considering risk management, institutional behavior and the impositions of risk as a kind of harm. Lewens (2007) for example, considers that the reflection of risk reveals significant theoretical gaps considering the choice between two alternatives options.

As a consequences, economics and finance study risk by examining the distribution of corporate returns (Fisher, 1969) while psychology, sociology and philosophy interpret risk in terms of its behavioral components (Olson and 
Desheng, 2008). Nonetheless, in the last decades we have seen some convergences between economist and psychology in the literature of economic behavior, a distinctive discipline of decision theory. The intention of this approach is to include the standard economic model of individual's formal rational action in the understanding of the way they actually think and behave (irrationality). In contrast to efficient market hypothesis behavioral economics would provide descriptive models in making judgments under uncertainty. Consequently we might see several disciplinary overlaps considering the concept of risk which is currently progressing with the emerging of new research on the topic.

Finally and for the purpose of this article we will select a definition of risk, which should be coherent with the objectives and scope of the document. The definition of risk that we will use for this article as being more consistent with the modern perspective of Risk Management ${ }^{1}$, is "the distribution of possible deviations from expected results and objectives due to events of uncertainty, which might be internal or external to the organization". In this perspective, the influence of risk factors could have then connotations of positive or negative and assumes the risk to be a generator of both potential losses and opportunities (Cleary and Malleret, 2007). Both elements together - the ambivalence of threat and opportunity as well as the chance to create the desired future - might explain why risk management has become so popular in business and politics (Cleary and Malleret, 2007). See figure 1 for an illustration of this perspective of risk.

1 As we will see further in this article, we mean for a modern perspective of Risk Management, a comprehensive, integrated and coordinated process within the organization to manage all kind of risks that its faces. 
Figure 1. Definition of risk

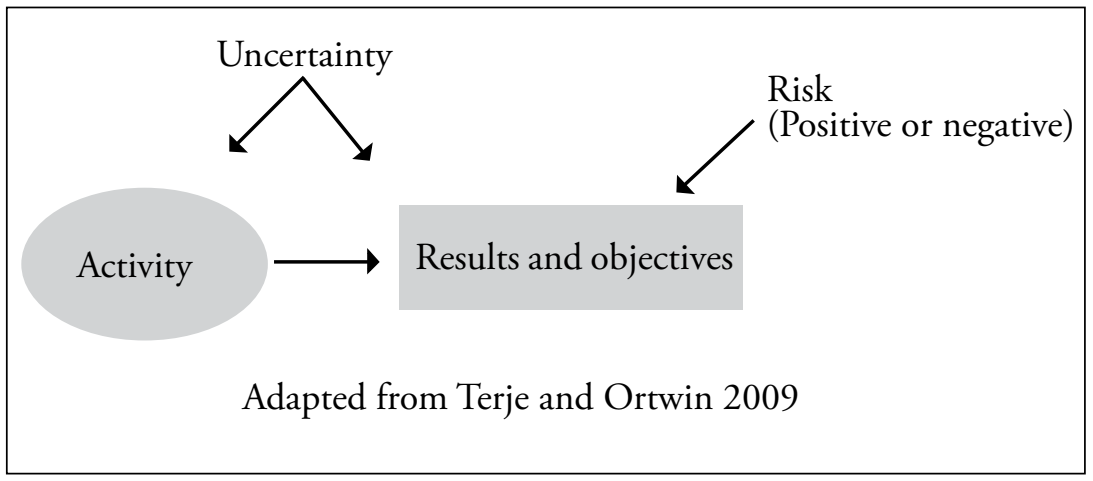

2. The distinction between Perils and Hazards, frequency, STATISTICS AND PROBABILITY

The terms peril and hazard are usually used interchangeably with each other and also with the concept of risk (Vaughan, 1997). Nonetheless it might be relevant to distinguish each concept for both theoretical and practical reasons. As mentioned by Vaughan, (1997) a peril would be the source of a loss. On the other hand, a hazard would be a condition that may create or increase the chance of a loss arising from a given peril. Therefore hazards would typically define the characteristics that would provide the potentiality for a loss. Flammability and toxicity are examples of such characteristics. Moreover it is important to make the distinction between a hazard and a risk because we can change the risk without changing a hazard. Stated by Vaughan, (1997) when a person crosses a busy street, the hazard should be clear to that person. In that sense, by placing himself in the path of moving vehicles the person is in a great hazard. The hazard would be then an injury or fatality as a result of being hit by a moving vehicle. The risk, however, would dependent on how that person conducts in the crossing of the street.

Moreover, frequency, statistics, and probability are also important concepts for the risk management discipline that we would need to mention. Frequency usually refers to a count of past observations. Statistics on the other hand, refers to the analyses of those past observations while the definition of probability is commonly distingue as the "degree of belief" which normally utilizes statistics but is rarely 
based entirely on them. As mentioned however by Lam, (2003), statistics by itself would not be probability since statistics would be a method or group methodologies to analyze numbers. Additionally, statistics assume that these numbers would be based on observations or past events that were numerally recorded. Consequently statistics do not imply anything about future events until inductive reasoning is employed. In that sense, in probability theory there would be a distinction between subjective and objective interpretations of the concepts (Moller, 2012). The objective interpretation would assume then to be property of the external world, as the propensity of a coin to land heads up. On the other hand according to the subjective interpretation, the probability of an event would be high considering the degree of belief that the event in question will occur according to that particular observer (Ramsey, 1931; Savage, 1972 in Moller, 2012). Therefore as stated to Moller (2012) if we are dealing with the repetition of technological procedures where the historical failure frequencies are known, it would be possible to determine what we might called objective probability. Nonetheless, in some cases that frequency data might not be available, consequently frequency data would be supplemented and often replaced by expert judgment (Moller, 2012).

Additionally as mentioned, extrapolating future failure probabilities from small amounts of information might lead to significant errors. Moreover and mentioned by Lam, (2003) as another possible problem with using historical data, would be the assumption that the conditions analyzed in the past would remain constant in the future. Consequently although important pieces of evidence and historical data alone might be sufficient to estimate failure, (Lam, 2003), we should acknowledge that they would not foretell the future, needing the organization to evaluate complementary sources of information and methods for their decision making process.

\section{Classification of Risk}

We might find different classification of risk in the literature that highlight certain properties or characteristics of risk. Therefore in general these different classifications would focus and indicate the sources of risk. As a consequence and for the purpose of this particular article, we have selected the following classifications: 
Financial and Non Financial. Mentioned by Vaughan (1997), the concept of risk in this sense would involve financial loss or consequences, but might also not include necessarily financial impact. Therefore under this perspective, financial risk involves the relationship between an individual (or an organization) and an asset or expectation of even an income that may be lost or damaged. Thus according to Vaughan (1997), financial risk involves three elements: (1) the individual or the organization who is exposed to loss, (2) the asset or income whose destruction or dispassion will cause financial loss, and (3) a peril that can cause the loss.

Dynamic and Static. Considering this classification, risk would be created by the dynamic change in the economic environment and would depend on both, the evolution of external variables - the economy, competitors, industry membership and consumers - and the decisions taken internally by the organization (Forestieri, 2003). Thus dynamic risks would normally benefit society over the long run, since they are the results of adjustment to the misallocation of resources (Vaughan, 1997). Nonetheless, dynamic risk could affect a great number of persons and they would believe to be less predictable than static risks, because they don't occur with any extent of regularity. On the other hand, static risks would be those risks that would be not dependable on the evaluation of the competitive environment in which the organization operates, but would rest merely on the internal factors of the entity. Unlike dynamic, static risks are predictable and would occur with some regularity. As mentioned by Pavodani and Tugnoli (2005), the mentioned principles of dynamic and statics risks would provide the basis elements for the reasoning on the transferring process of risks through the insurance market.

Systematic and Diversified. As mentioned by Vaughan, (1997) the source of systematic risk would be the main macroeconomic variables, such as the general tendency of economy (measured for example by the variation in GDP) and the tendency in market interest rates and inflation (measured, by the variation of the index of consumer prices). Often the sources of systematic risk are summarized by a single systematic risk factor, known as market risk. Therefore under this perspective, risks that are not tied to sources of systematic risk would be those diversifiable.

Pure and Speculative. Speculative risk would be often described in the literature as related to situation that hold a possibility of either loos or gain. Therefore these type of risks would not be insurable since they would involve a speculative 
process behind that might potentially rise to a profit (upside risk), but that could also lead to a loss (downside risk) (Pavodani and Tugnoli 2005). The concept of pure risk in contrast, is used to designate those situations that involve only the chance of loss or no loss. One of the best examples of pure risk would be the possibility of loss surrounding the ownership of property or any asset. In that case, the person who buys an automobile for example, immediately faces the possibility that something may happen to damage or destroy the automobile (Vaughan, 1997)

Fundamental and Particular. According to Culp (2001 in Pavodani and Tugnoli 2005), the distinction between fundamental and particular risks would be based on the difference in the origin and consequences of the losses. In that sense, fundamental risks would consider risks that would involve losses that are impersonal in origin and consequences (Vaughan, 1997). Therefore these types of risks would be caused in general by economic, social, and political phenomena, while they may also result from physical occurrences. Because fundamental risks would be caused by conditions beyond the control of the individuals who suffer the loss and since they would not the fault of anyone in particular, it is held that society rather than the individual would have a responsibility to deal with them (Vaughan, 1997). In that sense fundamental risks would affect a huge segment of the population. On the other hand, particular risks would refer to losses that occur in individual events and are experienced by individuals rather than groups. Thus particular risks are considered to be individual's owns responsibility and therefore are not a subject of concern of society as whole (Vaughan, 1997).

Core and non Core. The core of business risk, would be the risk that would be inherent to the type of activity performed by the organization. In this perspective this sort of risk would be the kind risk that would not be able to transfer and would need to be managed internally by the entity. As consequence, these kind of risks would become a potential source for expected incomes or return to the organization (Forestieri, 2003 in Pavodani and Tugnoli, 2005). Hence core or business risks would be manageable mainly through careful strategic choices.

The latter would mean to determine for instance, in which sectors and markets to invest, adopt centralize policies, and choose vertically integration or outsourcing strategies among others. On the other hand the non-core risk would be those 
risks to which the organization would be exposed as a result of any operational activity. Consequently in the case of non-core risks, they could be treated through strategic solutions or appropriate means of funding and insurance transfer.

Operational and Strategic. Normally the scholars that address the concept of the comprehensive or enterprise risk management approach (Drennan and McConnell, 2007; Fone and Young, 2005; Lam, 2003; Olson and Desheng, 2008 and Sadgrove, 2006 to mention a few), make also the distinction between strategic and operational risk. For these authors strategic risks would be related to issues that would require the organizations to think on a bigger scale. Therefore these type of risks would be managed at board level and require strategic planning (Sadgrove, 2006). In the case of local government for instances, this would be the case for the elected members, who would ensure that the correct policies procedures and delegations would be in place and that risk are managed appropriately within the organization. On the other hand, although operational risks would require the involvement of the highest hierarchy of the organization, they would be implemented in a lower level (Sadgrove, 2006). In that perspective operational risks would be present in the day to day functions and services of the organization. Accordingly such risks might derive from the people, property or processes involved in delivering the services expected or needed by the organization.

\section{An INTROdUCTION TO THE COMPREHENSIVE RISK MANAGEMENT APPROACH}

As we have mentioned, risk management has developed an enormous usability and popularity by the scientific world but also by organizations and practitioners. Therefore, although risk management has been always part of human kind and their organizations, it had to pass some decades before the integrated approach was finally understood and the benefits of its method came to the view for managers and decision makers. Therefore, we might say that the maximum evolution of "the art of Risk Management" as many authors refer to ${ }^{2}$, would be the comprehensive

2 Peter L Bernstein, “Against the God", 1996; Emmett J. Vaughan, "Risk Management", 1997; James Lam, "Enterprise Risk Management”, 2003; Martin Fone and Peter C. Young, "Managing Risks in Public Organizations, 2005; Lynn T. Drennan and Allan McConnell, "Risk and Crisis Management in the Public Sector", 2007 and many others. 
approach of the discipline which is often entitled as Enterprise Risk Management (ERM), Organizational Risk Management (ORM) or Corporate Risk Management among other distinctions ${ }^{3}$. Under this perspective, organizations are supposed to proactively manage risk, monitoring in a continue and conscious way the risks associated with their strategic objectives. The latter would indicate then, permanent measurement of the severity and evolution of risks within the organization, with the objective of maintaining an overall risk profile aligned with the strategic objectives of the organizations (Van Staveren 2009). The management of risk is therefore in this sense, an integral part of the organization and its processes, in the understanding that potential upside and downside factors can affect the organization. Accordingly, under this approach risk management would contribute to increase the possibility of success and reducing both, the probability of failure and the uncertainty of achieving the organizations overall objectives (AIRMIC, ALARM, IRM, 2002). From this point of view, each strategic and operational decision taken at all levels of the organization would be supported by the process of risk management. The main objective of risk management would be then according to this view, to understand in advance the impact of each alternative on the future performance of the organization (Hopkin 2002).

This integrated perspective of risk management started initially in the 90' and was formalized in 2004 by the Committee of Sponsoring Organizations of the Treadway Commission (COSO $)^{4}$. As mentioned by Arena (et al. 2010) $\mathrm{COSO}$ issued a guidance for building effective enterprise risk management, aiming to support managers at all levels of the decision making and planning process, as well as providing a guide for the design and implementation of a risk management program. COSO's stress out the requiring of senior management support for the implementation of enterprise risk management (ERM), as well as to focus on the risk analysis and control process. COSO's framework gives also an

3 There are other terms mentioned by Lam (2003) to describe this approach that include; "wide risk manager", "global risk manager", "integrated risk manager", and "holistic risk manager".

4 The Committee of Sponsoring Organizations of the Treadway Commission (COSO) is a voluntary private-sector organization, established in the United States in 1985, dedicated to providing guidance to executive management and governance entities on critical aspects of organizational governance, business ethics, internal control, enterprise risk management, fraud, and financial reporting. COSO has established a common internal control model against which companies and organizations may assess their control system. 
emphasis on establishing risk appetite as a necessary component of organizational consciousness, aspect that might be an incentive to the application of ERM at the strategic level of the organization (Power, 2007 in Arena et.al, 2010).

The comprehensive or enterprise risk management approach is often parallel to what is called by Lam (2003) as the "silo" perspective of risk management. The latter would be describe in the literature as an approach where the responsibility to handle a particular risk would be only assigned to units "threatened" by the risk (Lam, 2003). This would be the case especially for functions such as property protection, information security and health and safety, and in departments such as human resources, finance, education and social services. Hence under the "silo" approach there would be little sharing of information and even less sharing of techniques or methodologies with other functions or departments of the entity (Drennan and McConnell, 2007). Moreover, under this traditional or "silo" perspective of risk management, organizations would focus mainly in analyzing and treating "pure" risks.

On the contrary as we have mentioned, the comprehensive perspective of risk management would be oriented to consider all types of risk that an organization might face. This would mean as well leaving a purely "defensive" approach in favor of a proactive approach designed to increase organizational performance. As mentioned by Deloach (2000), enterprise risk management would be a structured approach that aligns strategy, processes, people, technology and knowledge with the objective to assess and manage threats and opportunities that companies face in trying to create value (Deloach, 2000). Under this perspective the risk management function within the organization would be responsible for the direct management of the risk management policy of the entity. The latter would consider the coordination with the all the operational and business areas of the organization, which would be ultimately responsible for the implementation of risk management, as well as performance a permanent monitoring procedure. Therefore this perspective of risk management would assume that whether at the planning stage of a new project or as a part of day to day strategic and operational management, risks would need to be managed in an integrated fashion, encompassing potential threats in each level of the entire organization (Drennan and McConnell, 2007). 
De Loach, (2000) in Pavodani and Tugnoli (2005), has summarized the differences between the integrated perspective of risk management and the silo approach by concluding that the traditional approach risk management is fragmented, reactive, focused on threats, discontinuous, functional and based on costs, while the comprehensive approach is integrated, proactive, focused on threats and opportunities, continuous and characterized by a logic process. This differences mentioned by De Loach would provide a guidance to analyze the dimensions to be used to differentiate the traditional approach of risk management from to integrated perspective. Specifically these authors state that for instance the relationship between risk management and strategy is more effective in the integrated approach of risk management. The latter would be justify considering that holistic perspective of risk management would require a top down approach with special and permanent support of the head of the organization. As Fone and Young (2005) also mention, strategic, operational, and modern risk management activities are not mutually exclusive, since the risk management component consist of those decisions and actions that facilitate the most direct achievement of organization objectives via its operation (Fone and Young, 2005). Additionally, the assessment of risk under this approach would be a repeated and formal process, with aspects of proactivity to anticipate threats and opportunities for the organization (De Loach, 2000 in Pavodani and Tugnoli (2005). Another specific difference of Enterprise Risk Management would be the relevance of risk communication, process that would be carried out through the whole organization, vertically toward the top management and horizontal given the nature of the cross process of integrated risk management. In table 1 and table 2 we present the main differences and key dimension of analysis of the integrated perspective of risk management.

\section{Table 2. Differences between Traditional Risk Management and Enterprise Risk Management}

\begin{tabular}{l|l} 
"Silo" Approach & \multicolumn{1}{|c}{ Comprehensive or ERM approach } \\
\hline - Fragment & -Integrated \\
- Reactive & •Proactive \\
-Discontinues & •Continuous \\
• Functions & $\bullet$ Base in process \\
\hline
\end{tabular}

Adapted from: De Loach 2000 in Pavodani and Tugnoli, 2005 


\section{Table 2. Key dimensions of analysis to confront the "silo" approach of risk management and the integrated approach}

\begin{tabular}{l|l|l} 
Key dimensions & \multicolumn{1}{|c|}{ "Silo" approach } & $\begin{array}{l}\text { Comprehensive or ERM } \\
\text { approach }\end{array}$ \\
$\begin{array}{l}\text { Relationship between RM and } \\
\text { strategy }\end{array}$ & $\begin{array}{l}\text { Limited influences of RM to } \\
\text { strategic planning }\end{array}$ & $\begin{array}{l}\text { Effective support of RM to } \\
\text { strategic planning }\end{array}$ \\
\hline Focus of the Risk Management & Focus only on the threats & $\begin{array}{l}\text { Focus on the threats and the } \\
\text { opportunities }\end{array}$ \\
\hline Assessment of Risk & Irregularly and reactively & $\begin{array}{l}\text { Repeated frequently and } \\
\text { with aspects of proactively }\end{array}$ \\
\hline Risk Management & "specialist" approach & $\begin{array}{l}\text { Centralize the management } \\
\text { of the risk }\end{array}$ \\
\hline Reporting of risk & $\begin{array}{l}\text { Risk mapping unstructured and } \\
\text { incomplete }\end{array}$ & $\begin{array}{l}\text { Consolidation of the risks with } \\
\text { clear and complete reports }\end{array}$ \\
\hline $\begin{array}{l}\text { Risk communication } \\
\text { organization }\end{array}$ & $\begin{array}{l}\text { Related to the affected function } \\
\text { on the particular exposure }\end{array}$ & $\begin{array}{l}\text { Vertical coordination towards } \\
\text { the top management and } \\
\text { horizontal given the nature of } \\
\text { risk management process. }\end{array}$ \\
\hline Liability risk & $\begin{array}{l}\text { Definition of responsibility is } \\
\text { often lacking certain types of risks }\end{array}$ & $\begin{array}{l}\text { Clear responsibility for all } \\
\text { the risks and subsequently } \\
\text { introduced a reward system. }\end{array}$ \\
\hline
\end{tabular}

Adapted from: Pavodani and Tugnoli, 2005, based on Spinardi, 2005

\section{The Risk Management Process}

As we have mentioned the integrated perspective of risk management would be structured in a process that includes a sequence of logical steps. The literature provides different approaches for the risk management process. Nevertheless and according to Van Staveren (2009), the risk management process or cycle would be compose at least of five stages: determining the objectives; identifying the risks; evaluating the risks; considering alternatives and selecting the risk treatment devices; and the implementing and reviewing stage.

As a consequence- and independently of the specific name- we can see in the literature that there would be always a first step where the entity should need to establish a clear objective for its risk management program. Or to put it in a 
simpler way, there would be a first decision by the entity in terms what would the organization like its risk management program to do (Vaughan, 1997). In that sense the possible objectives that the organizations might establish for the risk management program might vary. They could include maintaining the organization's survival or position in a specific sector, minimizing the cost associated with pure risk protecting employees from accidents that might cause serious injury among others (Vaughan, 1997). Under this perspective the literature prescribes that the objectives of the risk management program should be formalized in a "corporate of organizational risk management policy". The second step of a standard risk management process is related to the identification of the risks that the organization might face. The identification stage is normally performed by using several instruments such us internal records of the organization, insurance policy checklist, risk analysis questionnaires, flow process charts, analysis of financial statements, inspection of the firm's operations and interviews among others (Vaughan, 1997). Accordingly, the evaluation step involves measuring the potential size of the loss and the probability that it would actually occur, providing some ranking that would classify the risks in order of priorities. As a consequence, the evaluation step would provide critical information that would determine the attention that the organization might consider on certain risks. The forth step in the risk management process, has to do with the techniques or strategies that should be used to deal with each risk. The basic strategies frequently discussed in the literature are: avoidance, reduction, retention, and transfer. Therefore it is interesting to appreciate that this phase of the risk management process is primarily a problem in decision making, where the organization needs to decide among several types of risk management strategy (Cienfuegos, 2012). In the next step, the implementing stage, decisions that were established in the previous phase have to be implemented. The final step of the process of risk management would be about evaluating and reviewing the risk management program, establishing check and balance procedures in order to make sure that the objectives of the risk management program are accomplished.

Regarding risk management in public organizations we can mention the definition of the risk management process by Martin Fone and Peter C. Young (2005), who have done efforts in terms of translating these concepts to the public sector. These scholars also consider the first stage of the risk management process as a mission 
identification face, where the entity settles a goal for its risk management program. The second stage of the risk management process in this perspective, would deal with the identification, analysis and, measurement of risks. Additionally and for the third stage, there would be a risk control step, where the entity would have to decide whether to eliminate, avoid, reduce or prevent the risks identified and measured. The next stage of the risk management process according to Martin Fone and Peter C. Young (2005) would be the financing stage, where the entity should measure the financial consequences of the risks found. Finally under this perspective, the risk management process would be compose of a programmed administration stage, where the organization would need to implement the risk management program and the decisions related as well as including monitoring activities.

Continuing with the review of risk management processes for the public sector, we can mention as well the definition established by the UK risk management professional bodies, the Association of Insurance and Risk Managers (AIRMIC), the National Forum of Risk Management in Public Sector (ALARM) and the Institute of Risk Management (IRM). According to Drennan and McConnell (2007) this framework would be more a guidance document rather than a standard. We have to state as well that the so called UK standard utilizes the definitions of risks and risks-related terms approved by ISO. Thus, the UK standard characterizes the risk management process in also five steps. The first step of the risk management process under this approach is to identify an organization's exposure to uncertainty. The latter would require an intimate knowledge of the organization, the market in which it operates, the legal, social, political and cultural environment in which exists, as well as the development of a sound understanding of its strategic and operational objectives, including critical factors to its success and the threats and opportunities related to the achievement of these objectives (UK Standard, 2002). Consequently, this standard advises that risk identification should be approached in a methodical way to ensure that all significant activities within the organization have been identified and all the risks following from these activities are identify and categorize (see figure 4). Thus, business activities and decisions are classified in the following way by the UK Standard (2002):

- Strategic. Concern long term objectives of the organization that can be affected by areas as capital availability, political risks, legal and 
regularity changes, reputation and changes in the physical environment to mention a few.

- Operational. Concern the day-to-day issues that the organization is confronted with as it strives to deliver its strategic objectives.

- Financial. The effective management and control of the finances of the organization and the effects of external factors such as availability of credit, foreign exchanges rates, interest rate movement and other market exposures.

- Knowledge management. These concern the effective management and the control of the knowledge resources, the production, protection and communication.

- Compliance. The issues of health \& safety, environmental, trade descriptions, consumer protection, data protection, employment practices and regularity issues.

Moreover in the second step of the risk management process, the UK standard also considers an analysis step, which has the objective to identify risk in a structured format. In that sense by considering the consequence and probability of each of the risks the organization should be able to prioritize the key risks that would need to be analyzed in more detail. Under this perspective, the risk estimation is to be considered also a part of the analysis step. As established in this standard. Risk estimation can be quantitative, semiquantitative or qualitative in terms of the probability of occurrence and the possible consequences. Therefore, risk analysis ends establishing a risk profile of the organization which gives a significance rating to each risk and provides a tool for prioritizing risk treatment efforts. The process allows the risk to be mapped to the business area affected, describing the primary control procedures in place and indicating areas where the level of risk control investment might be increased, decreased or reapportioned (UK Standard, 2002).

The next step in terms of this standard is the evaluation step, which is used to make decisions about the significance of risks to the organizations and whether each specific risk should be accepted or treated. Additionally as a following step, this standard considers a risk reporting and communication step, which establishes different levels of information that should be distribute within the organizations. 
Therefore, the standard describes in a detailed manner the specific role that the board, (directors or council in local public entities) business units and individual should complete for the implementation of risk management within the organization. Moreover, the requirement of an external report in order to inform in a regular basis, about the objectives and effectiveness of the risk management program to the stakeholders, is another element that it is mentioned in this framework.

Furthermore the next step in the UK standard mentions a risk treatment stage, which refers to the process of selecting and implementing measures to modify the risk found (UK Standard, 2002). It is necessary to address that in this standard, risk financing refers to the mechanisms (e.g. insurance performance) for funding the financial consequences of risk. Risk financing is not generally considered to be the provision of funds to meet the cost of implementing risk treatment. This standard also highlights the necessity to prioritize risk control actions in terms of their potential to benefit the organization. Risk treatment is sometimes addressed also as 'strategies for responding to risk' (Drennan and McConnell, 2007) a topic that will have a specific space in this research because of its relevant in the risk management process. Finally the UK Standard (2002) mentions the monitoring and reviewing step as the last stage of the risk management process. This step aims to assure that risks are effectively identified and assessed and the appropriate controls and responds are in place. Regular audits of policy and standards compliance should be carried out and standards performance reviewed to identify opportunities for improvements. 


\section{The risk management process}

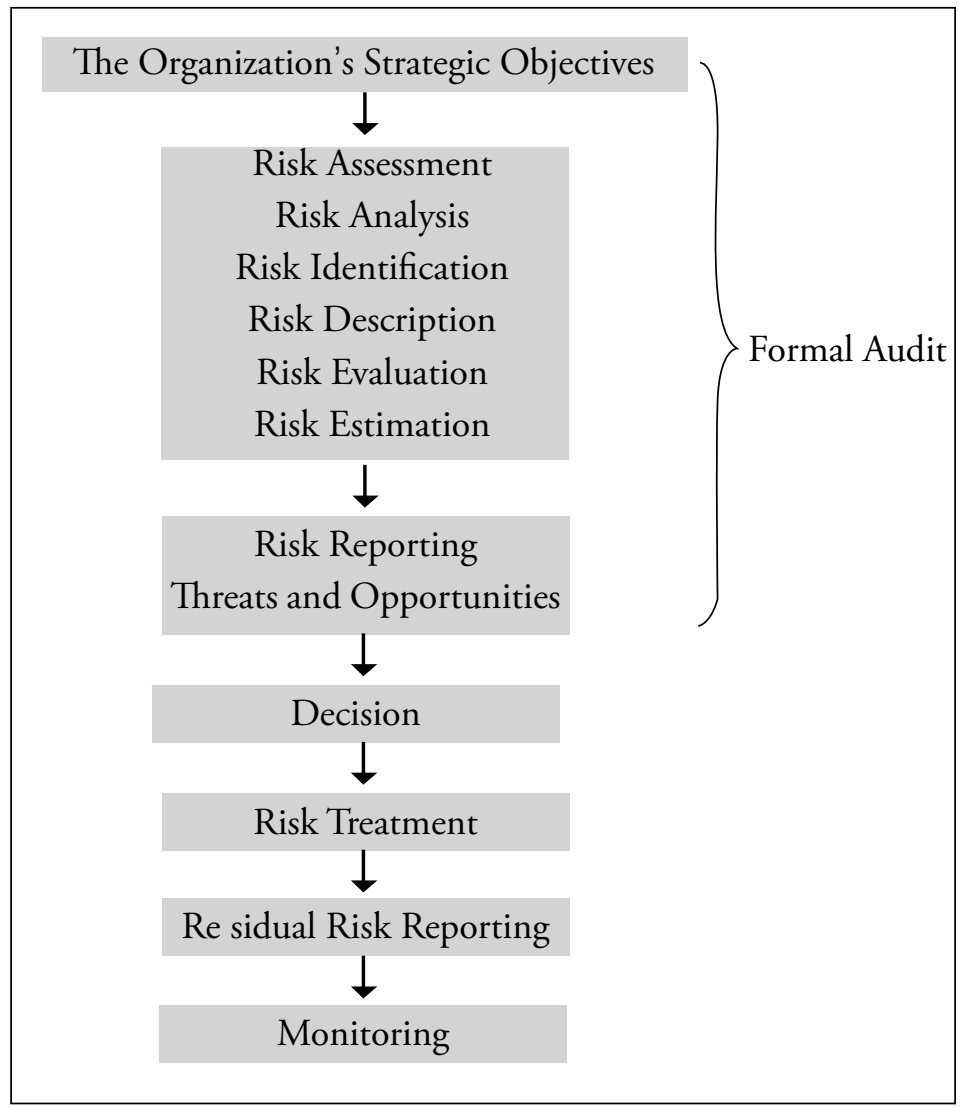

UK Standard 2002

\subsection{The Risk Management Strategies}

As we have previously discussed in this article, a fundamental part of the risk management function is about implementing procedures that would minimize the occurrence of loss or the financial impact of the ones that would occur anyway (Vaughan 1997). As Drennan and McConnell (2007) address, once current and potential risks have been identified and evaluated, decisions would be taken on how to respond and, in particular, what actions could be taken in order to improve future outcomes. Therefore a judgment is required to be made 
about the most appropriate response form a range of possible options. The latter could be performance taking into account the cost and benefits of each proposed action, as well as evaluating the probable reaction concerning these measures by stakeholders and other interested parties (Drennan and McConnell, 2007). As we have viewed in this article, this would require first a phase of analysis and assessment of risks attached to the organizations, followed by the implementation of the risk management strategy considered most appropriate for each type of risk. Therefore generally organizations would have the option to avoid (risk avoidance), reduce (risk reduction), transfer (risk transfer), retain (risk retention) or share (risk sharing) the risks that have been assessed (Knight, 2005).

Following the same considerations Vaughan (1997) identifies two broad dimensions to classify these techniques for dealing with risk, which are risk control and risk financing. Therefore according with this approach, risk control techniques would be designed to minimize, those risks to which the organization is exposed. As a consequence risk control methods include risk avoidance and the various approaches to reduce risk through loss prevention and control efforts. Risk avoidance would mean that the organization would refuse to accept any exposure to loss arising from a particular activity. Therefore as stated by Vaughan (1997) the non-risk taking is the recognition that there is no risk management measures that might reduce the risk below the limit considered acceptable for the organization in economic terms. On the other hand a strategy of risk reduction would aim to precisely limit the likelihood of occurrence of a loss event and the severity of the impact for the organization of those losses that might occur. Risk reduction can be conducted through prevention, meaning those activities that have the objective of preventing losses from occurrence and loss control, the efforts aimed at minimizing the severity of loss if it occurs (Vaughan 1997).

In contrast with risk control, risk financing focuses on guaranteeing the availability of funds to meet those losses that could occur. Fundamentally, risk financing takes the form of "retention" or "transfer". Therefore risk retention strategies would consider the maintaining of the risk within the company. As mentioned by Vaughan (1997) this strategy would be recommended when the risk is considered negligible or when the adoption of real measures to reduce would not be considered affordable. The retention of risk is a viable alternative and could be convenient one from the cost-benefit point of view. As a consequence the retention may be accompanied 
by specific budgetary or a fund to meet the deviation of expected losses (Vaughan 1997). Risk transfer strategy on the other side, would be related to the transfer of risk to a subject that would provide support in exchange of a premium. Risk transfer would imply in that sense, a contractual arrangements or the subcontracting of certain activities. The typical application of this strategy is the subscription of insurance against certain risks. However we might be observe strategies that could be situated between these two approaches (retention and transfer), approach that considers the sharing of the risks discovered with other organizations, through the establishment of a suitable agreement (e.g. public/private partnership).

When referring to authors who have researched specific risk strategies in public organizations we have to address again Drennan and McConnell (2007). They subscribe the concept of "tolerating risk", which involves accepting and retaining the risk (Drennan and McConnell, 2007). In this case a conscious decision to tolerate a risk would be the one that would require a regular monitoring, taking into account that circumstances may change and thereby shift the balance towards adopting a different strategy (Drennan and McConnell, 2007). According to these authors within the context of public organization, there would be a little choice but to tolerate certain threats 5 . In relation to strategies to eliminate or avoid risk, these scholars consider the concept of "terminating risk". The latter strategy would involve eliminating or avoiding the risk completely. This decision could be taken to terminate a risk by ceasing to offer a particular aspect of the service that has proven to be problematic, or to deliver it in a completely different way. In terms of strategies to transfer the risk, there would be no apparent distinction in the view of Drennan and McConnell, (2007); nonetheless they consider that the complete transfer of risk would be unusual, since in practical terms public organizations could just transfer part of the risks that the face. The concept of "treating risk" mentioned by Drennan and McConnell, (2007) could be assimilated as "risk control" and "risk prevention" in Vaughan's classification (1997). Risk controls methods may involve physical measures, changes in management systems, human resource strategies and risk financing alternatives.

5 For example, in the case of social welfare provision, there are rare occasions in which a case worker is attacked and injured by a mentally disturbed person whom they are visiting at home. Despite this threats, such visits are likely to continue -and the risk tolerated-as there is both a need for the home care of such individuals and little in the way of alternatives (Drennan and McConnell, 2007). 
Nonetheless as we have stated before, most risks can never be completely eliminated. As consequence, a "zero risk" approach would require the total control" future developments at the organization, which is practically impossible (Habegger, 2008). Moreover and considering the limited resources in the public arena, a carefully risk assessment needs to be done in order to balance the costs and benefits in public policy to risk mitigation. Additionally and mentioned by Drennan and McConnell, (2007) and Habegger, (2008), eliminating all risks may not even be desirable, as risks often incorporate an (undetected) opportunity and to take risks might be an important driver of innovation, economic growth, and social progress.

Finally we could say that the capability that the organization should develop in terms of risk management is to identify all forms of risk to which it is exposed and to understand, for each of them, the optimal risk management strategy. Consequently, decisions on risk strategy need to be establishing on a strong risk identification and evaluation process, and on the priorization of threats and opportunities. In table 4 we present review of the strategies reviewed in this section.

\section{Table 4. Summary of the Risk Management Strategies found in the literature}

\begin{tabular}{l|l|l}
\multicolumn{1}{c|}{ Strategies } & \multicolumn{1}{|c}{ Descriptions } \\
\cline { 2 - 3 } Risk Control & Risk avoidance & $\begin{array}{l}\text { Organization refuses to accept any exposure to loss } \\
\text { arising from a particular activity }\end{array}$ \\
\cline { 2 - 3 } & Risk prevention & $\begin{array}{l}\text { Eliminate the risk completely(refer by some scholars } \\
\text { as Risk avoidance) }\end{array}$ \\
\cline { 2 - 3 } & Risk reduction & $\begin{array}{l}\text { Limit the possibility of undesirable outcome being } \\
\text { realized (refer also by some Scholars as Risk reduction) }\end{array}$ \\
\cline { 2 - 3 } & Risk directive & $\begin{array}{l}\text { Limit the likelihood of occurrence of a loss and the } \\
\text { severity of the impact }\end{array}$ \\
\cline { 2 - 3 } Risk Financing & Risk detective & Identify undesirable outcomes experience after the event \\
\cline { 2 - 3 } & Risk corrective & $\begin{array}{l}\text { Correct undesirable outcome that have happened, } \\
\text { providing a route for recovering }\end{array}$ \\
\cline { 2 - 3 } & Risk retention & Maintain risk within the organization \\
\cline { 2 - 3 } & Risk toleration & Accepting and retaining the risk or opportunity \\
\cline { 2 - 3 } & Risk sharing & $\begin{array}{l}\text { Sharing the risk with other entities through the } \\
\text { establishment of a contract or agreement }\end{array}$ \\
\cline { 2 - 3 } & Risk transfer & $\begin{array}{l}\text { Transfer the risk to a subject that provides support in } \\
\text { exchange of a premium }\end{array}$ \\
\hline
\end{tabular}

Personal elaboration 


\section{Public Sector Risk Management}

As Drennan and McConnell (2007) mention public organizations would share much in common with both the private and not-profit organizations. They would face the same types of threats, to people, property and processes. Therefore according to these authors, the differences would lie in: a) the range of stakeholders to which the organizations is accountable, and, b) the extent to which political and social dimensions impact on decision taken (Drennan and McConnell, 2007). Nevertheless drawing distinctions between the public and private sectors is not straightforward as Fone and Young (2005) state. The distinctions might be rooted then in cultural and social factors; meaning 'public' would be whatever a society says it is (Fone and Young, 2005).

\subsection{Public Risk}

Nonetheless a general distinction could be made between public and private risk. We would have to say first though, as Fone and Young (2005) argue, that economic theory implies that efficient markets would be able to manage risks. The later might assume then that the efficient market would allocate the cost of responsibility for risks attendant on the product or services related with those risks. Nevertheless, as we know, some or perhaps many risks might not be suited to the 'market'. Pollution is again a good example of a risk that could damage the community, becoming what is known in the neoclassic economic theory, as market failure. In that sense, when we observe that the impact of a risk goes beyond the individual, we might start to seeing public risk emerge. Following the same perspective, Fone and Young, (2005) classified public risk in two different categories which are "social risk" and "organizational risk". As mentioned before, social risks would be those risk that affect society as a whole (epidemics, natural disasters and other catastrophes). On the other hand, organizational risks would be those risks that might affect the organization itself (liabilities, lawsuits, fire, financial risk, etc.).

Moreover a report by the UK Prime Minister's Strategy Unit (2002) recognizes three distinctions of the government's role considering risk that also aligns with the perspective presented by Fone and Young, (2005). 
- Regulatory- where individuals or business impose risks on others, government's role is mainly as regulator, setting the rules.

- Stewardship- where risks cannot be attributed to any specific individual or body, governments may take on a stewardship role to provide protection or mitigate the consequences.

- Management- in relation to their own business, including provision of services to citizens, governments are responsible for the identification and management of risks.

\subsection{Public Risk Management}

Taking the definitions by Fone and Young, (2005) of 'organizational' and 'social risk', we have to state that considering the focus of this article, we will concentrate now in the organizational perspective of public risk management. Accordingly, the same authors provide a classification of four dimensions where risk management would develops within the public entities. In this perspective, there would be first a political dimension within the public entity, where we could found specific threats and risk management applications. This would assume a relationship of the elected official with the citizens, from which we could extract the overall purpose of government and the legal dimension of institutional existence. Moreover, there would be also a strategic dimension for the risks that organizational entities face. This would mean that public organizations- as very organizations- would have a mission-objective formulation process. Furthermore, public organizations would have a tactical stratum where risk management would also serve a purpose. The tactical dimension would refer to risks related to budget execution and intermediaterange decision making. Finally, there would be an operational stratum in the organization, referring to risks related to day to day operations, short-term planning and execution, and functional performance (Fone and Young, 2005).

Particularly in the public sector, we can find evidence of the implementation of a formal risk management approach since the 1980's. As we might observe it as well in other industries and sectors, these practices tended to focus at beginning on the management of insurable risks (fires, thefts, liability exposures) 
and occasionally for occupational health and safety (Fone and Young, 2005). Nevertheless as Fone and Young, (2005) and Drennan and McConnell (2007) confirm, a number of aspects have contributed towards changing this narrow application of the risk management discipline in the public sector. In the first place, the implementation of the wider approach of ERM would demand that risk management move away from a constricted technical function to a broad and integrated management of all organization's risks. The latter characteristic of the integrated perspective of risk management, would be very much appreciated by public authorities, since it would contribute to the decision making process of public organizations. Additionally and normally requested by authorities, the implementation of corporate governance principals in public entities, has forced them to also incorporate risk management practices in the organizational culture. An example of this process is the adoption of national and international risk management standards by public organizations and the development of its own (i.e. AS/NZS 4360: 2004, UK 2002 standard).

An interesting policy considering risk management in the public sector can be found in the Netherlands. Since 1995 Dutch Municipalities and provinces have a bylaw that establishes a paragraph on risk management and from 2004 a paragraph on financial resilience. This bylaw creates a scrutiny of the available financial capacity and a scrutiny of the risks (the needed financial capacity) (Cienfuegos, 2012). It mentions as well the obligation of the development of a policy on the financial resilience and the identification of the risks and the measures taken within the local organizations.

Finally, in table 6 we present a review of the best risk management practices revised in this article which are organized by the risk management cycle or process, concept that was profusely revised on this paper and that was considered to be an essential part of the discipline of risk management. The source of these practices are the main and most well-known standards of the integrated approach of risk management such us; the COSO standard, AS/NZS, ISO 3100 and UK standard. We have also included in this selection the compilation of risk management practices reported in the work of MacGillivray, (2006) and Lam, (2003). 
Table. Process and practices selected form the literature research

\begin{tabular}{|c|c|c|}
\hline $\begin{array}{l}\text { Risk Manage- } \\
\text { ment Process }\end{array}$ & Practices identified & Source \\
\hline \multirow{7}{*}{$\begin{array}{l}\text { 1.Determining } \\
\text { the context and } \\
\text { formulating the } \\
\text { objectives }\end{array}$} & $\begin{array}{l}\text { 1.Establish mission, values and } \\
\text { strategy for applying integrated risk } \\
\text { management. }\end{array}$ & $\begin{array}{l}\text { MacGillivray, 2006, AS/ } \\
\text { NZS, 2004, ISO } 31000 \\
\text { 2009; COSO, 2004 and UK } \\
\text { standard, 2002). }\end{array}$ \\
\hline & $\begin{array}{l}\text { 2. The organization defines } \\
\text { objectives for the development of } \\
\text { the risk management program, } \\
\text { which contains the criteria and } \\
\text { recommendations of 'wider' } \\
\text { perspective and standards of risk } \\
\text { management. }\end{array}$ & $\begin{array}{l}\text { AS/NZS, 2004, ISO } 31000 \\
\text { 2009; COSO, } 2004 \text { and UK } \\
\text { standard, 2002. }\end{array}$ \\
\hline & $\begin{array}{l}\text { 3. Full commitment of top } \\
\text { management to risk, defines } \\
\text { objectives, gives rewards and requires } \\
\text { risk reporting. }\end{array}$ & $\begin{array}{l}\text { MacGillivray, } 2006 \text { and ISO } \\
\text { 31000, 2009; COSO, } 2004 \text {. }\end{array}$ \\
\hline & $\begin{array}{l}\text { 4. Establish a risk management } \\
\text { framework setting out the core roles } \\
\text { and responsibilities at strategic and } \\
\text { operational level. }\end{array}$ & $\begin{array}{l}\text { MacGillivray, 2006; ISO } \\
31000 \text { 2009; COSO, } 2004 \\
\text { and UK standard, 2002. }\end{array}$ \\
\hline & $\begin{array}{l}\text { 5. Identify key risk and opportunity } \\
\text { elements at the strategic level } \\
\text { and incorporate them in the risk } \\
\text { management program. }\end{array}$ & UK standard, 2002. \\
\hline & $\begin{array}{l}\text { 6. The organization considers } \\
\text { financial and non-financial risk that } \\
\text { might be present in the environment } \\
\text { whether they are political, legal or } \\
\text { economical. }\end{array}$ & $\begin{array}{l}\text { AS/NZS, 2004, ISO } 31000 \\
\text { 2009; COSO, } 2004 \text { and UK } \\
\text { standard, 2002). }\end{array}$ \\
\hline & $\begin{array}{l}\text { 7. Develop criteria indicating } \\
\text { how success and failure in risk } \\
\text { management will be measured. }\end{array}$ & $\begin{array}{l}\text { (MacGillivray, 2006; ISO } \\
31000 \text { 2009). }\end{array}$ \\
\hline
\end{tabular}




\begin{tabular}{|c|c|c|}
\hline $\begin{array}{l}\text { Risk Manage- } \\
\text { ment Process }\end{array}$ & Practices identified & Source \\
\hline \multirow{7}{*}{ 2.Identification } & $\begin{array}{l}\text { 8. The entity has a documented } \\
\text { standard repeatable process for } \\
\text { identifying risks and for the } \\
\text { improvement of the process. }\end{array}$ & $\begin{array}{l}\text { (MacGillivray, } 2006 \text { and ISO } \\
31000,2009 \text { ). }\end{array}$ \\
\hline & $\begin{array}{l}\text { 9. The entity develops a list of risks } \\
\text { based on those events that might } \\
\text { create, enhance, prevent, degrade, } \\
\text { accelerate or delay the achievement } \\
\text { of objectives, whether they are found } \\
\text { internally or externally, and whether } \\
\text { they are positive or negative. }\end{array}$ & (ISO 31000, 2009). \\
\hline & $\begin{array}{l}\text { 10. Risk identification should be } \\
\text { approached in a methodical way to } \\
\text { ensure that all significant activities } \\
\text { within the organization have been } \\
\text { identified and all the risks following } \\
\text { from these activities defined. }\end{array}$ & $\begin{array}{l}\text { (UK standard, 2002; ISO } \\
31000,2009) \text {. }\end{array}$ \\
\hline & $\begin{array}{l}\text { 11. The municipality has an intimate } \\
\text { knowledge of the context in which it } \\
\text { operates. }\end{array}$ & (UK standard, 2002). \\
\hline & $\begin{array}{l}\text { 12. Identify risks in strategic and } \\
\text { operational processes, as well as } \\
\text { financial and noon financial using } \\
\text { the range of techniques that are } \\
\text { available for this purpose. }\end{array}$ & $\begin{array}{l}\text { AS/NZS, } 2004 \text { and UK } \\
\text { standard, 2002). }\end{array}$ \\
\hline & $\begin{array}{l}\text { 13. Risk identification should be } \\
\text { informed by a risk register, which is } \\
\text { continually updated. }\end{array}$ & $\begin{array}{l}\text { MacGillivray, } 2006 \text { and ISO } \\
31000,2009) \text {. }\end{array}$ \\
\hline & $\begin{array}{l}\text { 14. Risk identification is developed } \\
\text { with the participation of key external } \\
\text { stakeholders as well as professionals } \\
\text { from different areas. }\end{array}$ & $\begin{array}{l}\text { (MacGillivray, 2006, ISO } \\
31000 \text { 2009; COSO, 2004; } \\
\text { UK standard, 2002). }\end{array}$ \\
\hline
\end{tabular}




\begin{tabular}{|c|c|c|}
\hline $\begin{array}{l}\text { Risk Manage- } \\
\text { ment Process }\end{array}$ & Practices identified & Source \\
\hline \multirow{8}{*}{$\begin{array}{l}\text { 3. Analysis, and } \\
\text { measurement } \\
\text { or prioritization } \\
\text { phase. }\end{array}$} & $\begin{array}{l}\text { 15. Risk is analyzed by determining } \\
\text { consequences and their likelihood. }\end{array}$ & $\begin{array}{l}\text { (MacGillivray, 2006, ISO } \\
31000 \text { 2009; COSO, 2004; } \\
\text { UK standard, 2002). }\end{array}$ \\
\hline & $\begin{array}{l}\text { 16. The interdependence of different } \\
\text { risks is also considered. }\end{array}$ & $\begin{array}{l}\text { (ISO 31000, } 2009 \text { and UK } \\
\text { standard, 2002). }\end{array}$ \\
\hline & $\begin{array}{l}\text { 17. The organization carries out } \\
\text { systematic risk analysis and uses } \\
\text { the best practices and tools for } \\
\text { measurement. }\end{array}$ & (UK standard, 2002). \\
\hline & $\begin{array}{l}\text { 18. Existing controls and their } \\
\text { effectiveness and efficiency should } \\
\text { also be taken into account. }\end{array}$ & $\begin{array}{l}\text { (ISO 31000, 2009, } \\
\text { MacGillivray, } 2006 \text { and UK } \\
\text { standard, 2002). }\end{array}$ \\
\hline & $\begin{array}{l}\text { 19. Organizations compare the } \\
\text { level of risk found with risk criteria } \\
\text { established or legally prescribed. }\end{array}$ & $\begin{array}{l}\text { ISO } 31000,2009 \text { and UK } \\
\text { standard, 2002). }\end{array}$ \\
\hline & $\begin{array}{l}\text { 20. The municipality has access } \\
\text { and uses external support from } \\
\text { expert to analyze the risk that they } \\
\text { have detected. }\end{array}$ & $\begin{array}{l}\text { MacGillivray, 2006, ISO } \\
31000 \text { 2009; COSO, 2004; } \\
\text { UK standard, 2002). }\end{array}$ \\
\hline & $\begin{array}{l}\text { 21. The information (outputs) of } \\
\text { risk analysis are collected, stored and } \\
\text { processed in the municipality, in a } \\
\text { qualitative and quantitative manner } \\
\text { that supports decisions in terms of } \\
\text { what strategies or responses use. }\end{array}$ & $\begin{array}{l}\text { (ISO 31000, } 2009 \text { and UK } \\
\text { standard, 2002). }\end{array}$ \\
\hline & $\begin{array}{l}\text { 22. Norms and assumptions } \\
\text { underpinning the design of the } \\
\text { risk analysis process are openly } \\
\text { questioned, critically evaluated and, } \\
\text { where appropriate, revised in light } \\
\text { of validation findings (i.e. double } \\
\text { loop learning). The validity of the } \\
\text { risk analysis process is questioned in } \\
\text { light of changes to regulations, best } \\
\text { practices and standards. }\end{array}$ & $\begin{array}{l}\text { MacGillivray, } 2006 \\
\text { COSO 31000, 2009). }\end{array}$ \\
\hline
\end{tabular}




\begin{tabular}{|c|c|c|}
\hline $\begin{array}{l}\text { Risk Manage- } \\
\text { ment Process }\end{array}$ & Practices identified & Source \\
\hline \multirow{7}{*}{$\begin{array}{l}\text { 4.Decision or } \\
\text { control }\end{array}$} & $\begin{array}{l}\text { 23. Select all possible risk strategies } \\
\text { (e.g. avoid, retain, reduce or transfer) } \\
\text { based on output from risk analysis } \\
\text { and evaluation. }\end{array}$ & $\begin{array}{l}\text { (MacGillivray, 2006; COSO, } \\
\text { 2004). }\end{array}$ \\
\hline & $\begin{array}{l}\text { 24. Effectiveness of the controls } \\
\text { are measured in terms of rational } \\
\text { methods, with regard also to legal, } \\
\text { regulatory, and other requirements } \\
\text { such as social responsibility and } \\
\text { the protection of the natural } \\
\text { environment. }\end{array}$ & $\begin{array}{l}\text { (ISO 31000, } 2009 \text { and UK } \\
\text { standard, 2002) }\end{array}$ \\
\hline & $\begin{array}{l}\text { 25. The organization adopts a } \\
\text { combination of treatment options for } \\
\text { the risk that has identified, not just } \\
\text { individual (single controls) strategies. }\end{array}$ & $\begin{array}{l}\text { (ISO 31000, 2009, UK } \\
\text { standard, 2002 and COSO } \\
31000,2009) .\end{array}$ \\
\hline & $\begin{array}{l}\text { 26. When selecting risk treatment, } \\
\text { the organization considers the } \\
\text { perceptions of stakeholders. }\end{array}$ & (ISO 31000, 2009). \\
\hline & $\begin{array}{l}27 . \text { The organization establishes } \\
\text { indicators to track the progress of } \\
\text { risk response. }\end{array}$ & $\begin{array}{l}\text { MacGillivray, 2006; COSO, } \\
\text { 2004). }\end{array}$ \\
\hline & $\begin{array}{l}\text { 28. Risk response strategies are } \\
\text { implemented in light of risk } \\
\text { analysis output }\end{array}$ & $\begin{array}{l}\text { (MacGillivray, 2006; ISO } \\
\text { 31000, 2009, UK standard, } \\
\text { 2002). }\end{array}$ \\
\hline & $\begin{array}{l}\text { 29. Risk strategies are treated as } \\
\text { a secondary risks that need to be } \\
\text { assessed, treated, monitored and } \\
\text { reviewed. }\end{array}$ & (ISO 31000, 2009). \\
\hline
\end{tabular}




\section{Risk Manage-} ment Process
5.Implementation reviewing or feedback.

\section{Practices identified}

\section{Source}

30. There is a formal monitoring process within the organization that provides assurance that there are controls in place, which considers also feedback from stakeholders and experts.

31. The organization has external support from experts and top management for the implementation of the risk management program.

(ISO 31000, 2009; UK standard, 2002).

32. Define roles, responsibilities and (MacGillivray, 2006, ISO timescales for implementing risk 31000 2009; and COSO, management. 2004). 33. Allocate resourcing for the (MacGillivray, 2006, ISO implementation of risk management.

34. Define criteria for risk monitoring activities.

(ISO $31000 \quad 2009 ;$ and COSO, 2004 ISO 31000, 2009) ISO 31000, 2009). 2004; Lam, 2003).

(MacGillivray, 2006, ISO 31000 2009; and COSO, 2004).

35. Integrate the process of risk MacGillivray, 2006; ISO management within the organization 31000 2009; Drennan and through establishing reward McConnell, 2007; Lam, 2003 mechanisms. and COSO, 2004).

36. Define and implement an (MacGillivray, 2006; ISO organizational strategy for the 31000 2009; and COSO, $\begin{array}{ll}\text { management of change. } & \text { 2004). }\end{array}$

37. Define annually education and training requirements for risk management (i.e. competency requirements).

(MacGillivray, 2006, ISO 31000 2009; Lam, 2003 and COSO, 2004).

38. The organization defines data / reporting requirements for effective risk management, which are used by decision makers

(MacGillivray, 2006, ISO 31000 2009; Lam, 2003 and COSO, 2004).

39. The organization implement risk management systems and infrastructure to capture, analyze and distribute the required data / information according with the best practices and standards.

40. Regular audits are carried out to receive feedback and identify opportunities for improvement.
MacGillivray, 2006, ISO 31000 2009; and COSO, 2004).

(ISO 310002009 and UK standard, 2002). 


\section{Conclusions}

In this article we have studied in a normative manner, the theoretical fundaments of the discipline of risk management, reviewing also its development and best practices. We have also paid special attention to the application of risk management in the public sector, as well as the risk management process as the formal and logic method to implement the management practices in any organization. Additionally and after a quick description of the current environment into which organizations struggle we proceed to identify a definition of risk and risk management.

Moreover by reviewing the literature, we have made a clear distinction between the traditional or "silo" perspective of risk management from its maxim evolution, the comprehensive risk management approach. Therefore we have learned that the literature prescribes that under this perspective, organizations need to monitor their risk in a continue and conscious way specially the ones associated with its strategic objectives, measuring as well the severity and evolution of them, with the objective of maintaining an overall risk profile aligned with the level agreed with the stakeholders of the organizations and at the same time compatible with the strategic objectives (Van Staveren 2009). As a consequence and despite some different labeling, we can observe a consensus in the literature of risk management considering the best practices (i.e. AS/NZS 4360, 2004; COSO, 2004; ISO, 2002 and UK standard, 2002). Thus for instance, we can see significant evidence in the literature related to the importance of reports, information system, corporate governance and communication in the process of implementing a risk management program. Furthermore the literature stress out the fact that risk management risk management practices should exist and disseminate throughout the whole organization. Moreover the literature on the integrated perspective addresses the necessity of considers both perils and opportunities when implementing a risk management program. Additionally the literature on the compressive perspective gives importance to incorporation in the organization of the role of risk manager as a role that might technically assist the board of directors or Council in the case of a local public entity. Nonetheless also mentioned by the literature (Young, 2000), the directors should be ultimately responsible and accountable for managing risk in the organization and ideally "everyone" in the organization should be a risk manager. Finally we could say that the literature and standards of risk management 
gives also consideration to ensure adequate resources to the implementation of risk management. The latter assumes the development of the require capabilities in the organization, the implementation of a documented process and a risk management system of information.

\section{REFERENCES}

ALARM (2009) The Alarm National Performance Model for Risk Management in the Public Services. UK: The Public Risk Management Association.

ALARM (2002). A Risk Management Standard. UK: The Public Risk Management Association. AIRMIC, ALARM, IRM.

Arena, M., Arnaboldi, M., Azzone, G. (2010). "The organizational dynamics of Enterprise Risk Management”. Accounting, Organizations and Science. Vol. 35, pp. 659-675.

Arrow, Kenneth (1965). Aspects of the Theory of Risk Bearing. Helsinki: Yrjo Jahnssonis Saatio.

Aven, T. (2003). Foundations of risk analysis: A knowledge and decision-oriented perspective. New York: Wiley.

Aven T., (2007). "A unified framework for risk and vulnerability analysis and management covering both safety and security". Reliability Engineering and System Safety Vol. 92, pp. 745-754.

Babcock, G.C., (1972). "A note on justifying Beta as a measure of risk". The Journal of Finance, Vol. 27, N³, pp. 699-702.

Bailes, Alyson J. K. (2007). "Introduction: A World of Risk". SIPRI Yearbook 2007: Armaments, Disarmament and International Security. Stockholm: SIPRI.

Banse, G. and Bechmann, G., (1998). Interdisziplinäre Risikoforschung: Eine Bib-liographie. Opladen: Westdeutscher Verlag.

Beck, U. (1992). Risk society: Toward a new modernity. M.A. Ritter. London: Sage

Bernstein, Peter L. (1998). Against the Gods, the Remarkable Story of Risk. USA: John Wiley \& Sons.

Binmore K (2009). Game Theory and the Social Contract. University College London.

Boholm, Å. (1998). “Comparative studies of risk perception: a review of twenty years of research”. Journal of Risk Research, Vol. 1, N², pp. 135-163.

Cabinet Office (2002). Risk: Improving government's capability to handle risk and uncertainty. London: Strategy Unit.

Campbell, S. (2005). "Determining overall risk". Journal of Risk Research Vol. 8, pp. 569 - 581 
Cienfuegos I., (2011). "Risk Management Policy in Dutch Municipalities: Understanding the process, identifying its strengths and visualizing the possible improvements". Revista Enfoques, Ciencia Politica y Administración Pública, Vol. VIII No 14, pp.155-176

Cienfuegos Ignacio, (2012). "Decision Theory and Risk Management in Public Organizations: A Literature Review”. Revista de Gestión Pública. Vol. 1, N¹. pp.101-126

Cleary, S., and Thierry M., (2007). Global Risk: Business Success in Turbulent Times. New York: Palgrave Macmillan.

COSO (2004). Enterprise risk management - integrated framework. Committee of Sponsoring Organizations of the Tread way Commission.

Culp, C. (2001). The Risk Managememnt Process: Business Strategy and Tactics. Canada: John Wiley \& Sons

D’Arcy S. and, Brogan J. (2001). "Behavioral Economics. Faculty Scholar in Risk Management and Insurance and Professor of Finance". Journal of Risk Management of Korea Vol. 12, N 1. pp. 207-228.

Deloach, J. (2000). Enterprise-wide Risk Management: Strategies for linking risk and opportunity. FT Prentice Hall.

Douglas, Mary and Wildavsky, Aaron (1982). Risk and culture: an essay on the selection of technical and environmental dangers. University of California Press.

Drennan, Lynn T. and McConnell, Allan (2007). Risk and Crisis Management in the Public Sector. Routledge.

Eeckhoudt, L., Gollier, C., and Schlesinger, H. (1996). "Changes in background risk and risk raking behavior”. Econometrica Vol. 64, N³, pp. 683-689.

Fisher, I.N., and Hall, G.R., (1969), "Risk and corporate rates of return". The Quarterly Journal of Economics 83:1, 79-92.

Forestieri, G. (2003). Corporate and investment banking. Milano: EGEA.

Frank, M.V., (1999). "Treatment of uncertainties in space and nuclear risk assessment with examples from Cassini mission implications”. Reliability Engineering and System Safety, Vol. 66, pp. 203-21.

Friedman, M., and Savage, L.J. (1948). "The utility analysis of choices involving risk”. The Journal of Political Economy Vol. 56, N4, pp. 279-304.

Fone, Martin and. Young, Peter C (2000). Public Sector Risk Management. Biddles.

Gehr, A.K., (1979), "Risk and Return”. The Journal of Finance Vol. 34, N4, pp. 1027-1030.

Graham, J.D., and J.B. Weiner, eds. (1995). Risk versus risk: Tradeoffs in protecting health and the environment. Cambridge: Harvard University Press. 
Habegger, Beat (2008). "Risk Management in Public Policy". International Studies Association $49^{\text {th }}$ Annual Convention San Francisco, USA.

Hansson, S.O., (1998). Setting the limit: occupational health standards and the limits of science. Oxford: Oxford University Press.

Hermans, M.A., Fox, T. and van Asselt (2012). "Risk Governance”. In S. Roeser R. Hillerbrand, P. Sandin, M. Peterson (eds), Handbook of Risk Theory. Springer Science + Business Media.

Hillson, David A. (1997). “Towards a Risk Maturity Model”. The International Journal of Project \& Bussiness Risk Management, Vol.1, №1, pp. 35-45

Hillson, David, (2006). The Risk Management Universe. BSI

Hopkin, P., (2002). Holistic Risk Management in Practice. London: Witherby.

ISO. 2002. Risk management vocabulary. ISO/IEC Guide 73. Geneva: ISO.

IRGC (2005). "White paper on risk governance". Towards an integrative approach. Geneva: IRGC.

Joint Standards Australia/Standards New Zealand Ccomitte OB-007, Risk Management (2004). Risk Management, AS/NZS 4360:2004. Standards Australia/Standards New Zealand.

Kaplan, S. (1991). "Risk assessment and risk management - basic concepts and terminology". In Risk management: Expanding horizons in nuclear power and other industries. Boston, MA: Hemisphere Publ. Corp.

Kaplan, S., and B.J. Garrick. (1981). "On the quantitative definition of risk". Risk Analysis Vol. 1, pp. 11-27.

Kawamoto, B. (2001). "Issues in Enterprise Risk Management: From Theory to Application". Casualty Actuarial Society Spring Meeting.

Knight, F. (1921). Risk, Uncertainty and Profit. New York: Harper \& Row.

Knight, K. (2005). "Risk Management: a Journey not a Destination" on line: www.sincert.it.

Lam, J., (2003). Enterprise Risk Management, From Incentives to Controls. USA: John Wiley \& Sons.

Lewens, T., (2007). Risk: Philosophical Perspectives. USA: Routledge.

Lowrance, W. (1976). Of acceptable risk - science and the determination of safety. Los Altos, CA: William Kaufmann Inc.

MacGillivray, B. H., Hamilton, P. D., Strutt, J. E. and Pollard, S. J. T. (2006a). "Risk analysis strategies in the water utility sector: an inventory of applications for better and more credible decisionmaking". Critical Reviews in Environmental Science and Technology, Vol. 36, pp. 85-139.

MacGillivray, B. H., Pollard, S. J. T., Hamilton, P. D. and Bradshaw, R. A. (2006b), “Benchmarking risk management within the international water utility sector. Part II: A survey of eight water utilities", Journal of Risk Research, Vol. 10, N¹, pp. 105-123. 
Markowitz, Harry M. (1952). "Portfolio Selection”. Journal of Finance vol. 7, pp. 77-91.

Moller, N., (2012), "The Concepts of Risk and Safety”. In S.Roeser, R. Hillerbrand and M. Peterson (eds.) Handbook of Risk Theory. Springer Science + Business Media.

Olson, D. (1995). Decision Aids for Selection Problems. New York: Springer Verlag.

Olson D., and Desheng W., (2008). New Frontiers in Enterprise Risk Management. Springer.

Padovani, Roberto and Tugnoli, Andrea (2005). L'Enterprise Risk Management Nelle Imprese Non Finanziarie: Aspetti Teorici e Studi Di Caso Nel Mercato Italiano. Italia: Politecnico Di Milano, Facolta Di Ingegneria Dei Sistemi.

Power, M. (2007). Organized Uncertainty. New York: Oxford University Press, Inc.

Ramsey, F., (1931). “Truth and probability”. In: Braithwaite RB (ed). The foundations of mathematics and other logical essays. London: Routledge (Reprinted in: Gardenfors P, Sahlin N-E (eds). Decision probability, and utility. Cambridge University Press, Cambridge).

Rayner, S. (1998). "Culture theory and risk analysis". In S. Krimsky and D. Golding (ed.) Social theories of risk. Westport, CT: Praeger.

Renn, Ortwin (1981). "Man, technology, and risk: a study on intuitive risk assessment and attitudes towards nuclear energy”. Jülich, Bundesrepublik Deutschland: Zentralbibliothek der Kernforschungsanlage.

Renn, Ortwin (1998). "Three decades of risk research: accomplishments and new challenges". Journal of Risk Research, Vol.1, №1, pp. 49-71.

Renn, Ortwin (1992). “Concepts of Risk: A Classification”. In Krimsky, Sheldon and Dominic Golding (eds.), Social Theories of Risk. Westport: Prager, pp. 53-79.

Rosa, E.A. (1998). “Metatheoretical foundations for post-normal risk”. Journal of Risk Research Vol. 1 , pp. $15-44$.

Rosa, E.A. (2003). "The logical structure of the social amplification of risk framework (SARF): Metatheoretical foundation and policy implications". In N. Pidegeon, R.E. Kaspersen and P. Slovic (eds) The social amplification of risk. Cambridge: Cambridge University Press.

Sadgrove, K., (1996). The Complete Guide to Business Risk Management. UK: Gower.

Savage, L.J. (1954). The Foundations of Statistics. New York: Wiley.

Shapiro, Sidney A. and Schroeder, Christopher (2008). "Beyond Cost-Benefit Analysis; A Pragmatic Reorientation”. Research Paper $\mathrm{N}^{\circ}$ 1087796. Wake Forest legal Studies Research Paper Series.

Shapiro, A.C., and Titman, S. (1986). "An Integrated approaches to corporate risk management". In Stern, J.M., and Chew, D.H. (eds.). The Revolution in Corporate Finance. Oxford: Blackwell. 
Shrader-Frechette, K. (1985). Risk analysis and scientific method: Methodological and ethical problems with evaluation societal hazards. Dordrecht: Reidel.

Slovic, Paul; Griffin, Dale and Tversky, Amos (1990). "Compatibility effects in judgments and choice". In Robin Hogarth (ed.) Insight in Decision Making: A tribute to Hillel J. Einhorn. USA: Chicago University Press.

Slovic, P., (1987). “Perception of risk”. Science Vol. 236, pp. 280-285.

Slovic, P. (1997). "Public perception of risk”. Journal of Environmental Health, Vol. 59, N9, pp. 22-23

Slovic, P, Baruchf I., and Ichtenstein, S., (1977). "Behavioral Decision Theory Annual Review of Psychology, Vol. 28, pp.1-39.

Slovic, P., Monahan, J., MacGregor, D.M., (2000). "Violence risk assessment and risk communication: The effects of using actual cases, providing instructions, and employing probability vs. frequency formats". Law and Human Behavior Vol. 24, N³, pp. 271-296.

Taylor, F.W. (1911). Scientific Management. New York: Harper \& Row, Publishers, Inc.

Terje A. and Ortwin R., (2009) "On risk defined as an event where the outcome is uncertain" Journal of Risk Research, Vol. 12, $\mathrm{N}^{\circ} 1$, pp. 1-11.

Thompson, P.B., and W. Dean (1996). “Competing conceptions of risk". http://www.piercelaw. $\mathrm{edu} / \mathrm{risk} / \mathrm{vol} / \mathrm{fall} / \mathrm{thompson} . \mathrm{htm}$.

UK Prime Minister's Strategy Unit, (2002). http://www.cabinetoffice.gov.uk/strategy.aspx

UK Resilience (2006). Comunication Risk. London: Cabinet Office.

Van Staveren, Martin (2009). "Risk Innovation and Change". The Netherlands: Ipskamp Drukkers, B.V., Enschede.

Vaughan, Emmett J. (1997). Risk Management. USA: John Wiley \& Sons.

Willet, A. (1951). The Economic Theory of Risk and Insurance. Pennsylvania: Columbia University Press.

Webster M. (1983). Collegiate Dictionary. Britannica Company.

Willis, H.H. (2007). "Guiding resource allocations based on terrorism risk". Risk Analysis Vol. 27, pp. 597-606.

Young, P., (2000). “Enterprise Risk Management: Another Perspective”. Risk \& Insurance magazine. 